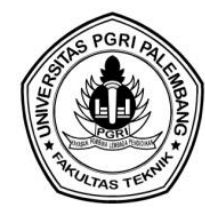

\title{
PENGARUH PENAMBAHAN LIMBAH SERBUK GERGAJI DAN KERTAS TERHADAP KUAT TEKAN BETON TANPA PERLAKUAN KHUSUS
}

\author{
Herri Purwanto \\ Prodi Teknik Sipil, Fakultas Teknik, Universitas PGRI Palembang \\ Email : irwanto1969@gmail.com
}

\begin{abstract}
ABSTRAK
Beton akan dapat mencapai mutu tertentu, sangat tergantung dari campuran beton yang digunakan, semakin bagus dan baik campuran beton yang digunakan, akan semakin baik dan bagus pula mutu beton yang dihasilkan. Tetapi dalam pelaksanaan pekerjaan di lapangan (lokasi pekerjaan) sering terjadi kecerobohan atau faktor yang tidak disengaja, sehingga campuran yang dibuat tercampur dengan material lain yang tidak diharapkan seperti limbah konstruksi atau limbah rumah tangga.Tujuan dilakukan penelitian ini adalah untuk mengetahui pengaruh penambahan limbah serbuk gergaji dan kertas terhadap kuat tekan beton tanpa perlakuan khusus. Dari hasil pengujian diperoleh kuat tekan beton normal (tanpa penambahan serbuk gergaji dan kertas) sebesar 144,46 kg/cm2, penambahan serbuk gergaji $5 \%$ dan kertas $5 \%$ kuat tekan 132,61 kg/cm2, penambahan serbuk gergaji 5\% dan kertas $10 \%$ kuat tekan $89,28 \mathrm{~kg} / \mathrm{cm} 2$, penambahan serbuk gergaji $5 \%$ dan kertas $15 \%$ kuat tekan $82.30 \mathrm{~kg} / \mathrm{cm} 2$, penambahan serbuk gergaji $10 \%$ dan kertas $5 \%$ kuat gergaji $104.05 \mathrm{~kg} / \mathrm{cm} 2$, penambahan serbuk gergaji $15 \%$ dan kertas $5 \%$ kuat tekan $110,67 \mathrm{~kg} / \mathrm{cm} 2$. Dari hasil pengujian kuat tekan beton tersebut, terjadi penurunan kuat tekan dari setiap campuran, dan kuat tekan beton terbesar yaitu 132,61 kg/cm2 terjadi di komposisi campuran beton normal ditambah serbuk gergaji 5\% dan kertas 5\%. Sehingga dapat disimpulkan bahwa campuran beton normal ditambah serbuk gergaji dan kertas dengan pelaksanaan tanpa perlakuan khusus tidak mencapai mutu beton K.175 adukan 1:2:3 yang diharapkan.
\end{abstract}

Kata Kunci : Beton, Serbuk Gergaji, Kertas, Kuat Tekan, Mutu K.175

\begin{abstract}
Concrete will be able to achieve a certain quality, it really depends on the concrete mixture used, the better and better the concrete mixture used, the better and better the quality of the concrete produced. But in the implementation of work in the field (work location), carelessness or unintentional factors often occur, so that the mixture is mixed with other unexpected materials such as construction waste or household waste. The purpose of this research is to determine the effect of the addition of sawdust waste and paper against the compressive strength of concrete without special treatment. From the test results obtained the normal concrete compressive strength (without the addition of sawdust and paper) of $144.46 \mathrm{~kg} / \mathrm{cm} 2$, addition of $5 \%$ sawdust and $5 \%$ paper compressive strength of $132.61 \mathrm{~kg} / \mathrm{cm} 2$, addition of $5 \%$ sawdust and paper 10 $\%$ compressive strength $89.28 \mathrm{~kg} / \mathrm{cm} 2$, addition of $5 \%$ sawdust and paper $15 \%$ compressive strength of $82.30 \mathrm{~kg} / \mathrm{cm} 2$, addition of $10 \%$ sawdust and paper $5 \%$ compressive strength of $104.05 \mathrm{~kg} / \mathrm{cm} 2$, addition of $15 \%$ sawdust and paper $5 \%$ compressive strength $110.67 \mathrm{~kg} / \mathrm{cm} 2$. From the results of the concrete compressive strength test, there was a decrease in the compressive strength of each mixture, and the largest concrete compressive strength, namely $132.61 \mathrm{~kg} / \mathrm{cm} 2$, occurred in the composition of normal concrete mixture plus 5\% sawdust and 5\% paper. So it can be concluded that the normal concrete mixture plus sawdust and paper without special treatment does not achieve the expected quality of K.175 1: 2: 3 concrete mix
\end{abstract}

Keywords: Concrete, Sawdust, Paper, Compressive Strength, Quality K.175 


\section{PENDAHULUAN}

Beton akan dapat mencapai mutu tertentu, sangat tergantung dari campuran beton yang digunakan, semakin bagus dan baik campuran beton yang digunakan, akan semakin baik dan bagus pula mutu beton yang dihasilkan. Menurut Purwanto (2016), penggunaan beton bertulang yang dibuat di lokasi (cast-in situ), kualitas beton yang diharapkan dalam pelaksanaannya sering tidak tercapai, hal ini dikarenakan pelaksana dan pekerja kurang memahamami pentingnya mutu suatu konstruksi. Faktor penyebab terjadinya hal tersebut karena standar minimum material yang digunakan dalam pelaksanaan pekerjaan beton tidak mengikuti spesifikasi teknis yang dipersyaratkan, begitupun dalam penggunaan peralatan, dimana peralatannya tidak berfungsi dengan baik dan tidak layak pakai. Begitu juga dengan sumber daya manusianya yang bukan tenaga ahli dan terampil di bidangnya. Dalam pelaksanaannya di lapangan (di lokasi pekerjaan) kadang terjadi kecerobohan yang tidak disengaja, yang menyebabkan campuran beton yang dibuat tercampur material lain, seperti limbah konstruksi atau limbah rumah tangga. Tetapi terkadang pencampuran tersebut sengaja dilakukan guna memanfaatkan material yang ada yang dianggap layak sebagai campuran beton. Oleh karenba itu, guna mengetahui kekuatan maksimal suatu campuran beton, maka perlu dilakukan kajian penelitian terhadap campuran tersebut. Sehingga diharapkan kedepan dapat dimanfaatkan suatu limbah sebagai campuran konstruksi beton

Dalam kajian ini, memanfaatkan limbah serbuk kayu yang dicampur dengan limbah kertas sebagai campuran pembuatan beton dengan kondisi sampai maksimal yang bisa dihasilkan mutu betonnya dengan tanpa perlakuan khusus. Tanpa perlakuan khusus yang dimaksudkan disini adalah pembuatan campuran beton dengan penggunaan agregat (pasir dan batu pecah) serta penambahan limbah kayu dan kertas tanpa dibersihkan (dicuci) terlebih dahulu, dengan berasumsi bahwa pelaksanaan pencampuran material di lapangan (tempat pekerjaan) tanpa ada proses pencucian material terlebih dahulu, sehingga diharapkan dapat diketahui mutu beton yang sesuai kondisi pelaksanaan lapangan. Dan tujuan kajian ini adalah untuk mengetahui seberapa besar pengaruh penambahan limbah serbuk kayu dan kertas terhadap kuat tekan beton tanpa perlakuan khusus

Saifuddin, dkk (2013) didalam penelitiannya menyatakan, pada serbuk kayu Kulim dari Desa Rambah dan Tengah Hilir Kabupaten Rokan Hulu-Riau mengandung kadar selulosa dan hemiselulosa, dimana apabila pada saat proses pembentukan beton, campuran semen dan pasir ditambah serbuk kayu Kulim tersebut, maka senyawa yang terkandung dalam serbuk kayu tersebut akan terserap pada permukaan mineral/partikel dan akan menambah kekuatan ikat antar partikel. Hal ini diakibatkan karena sifat adhesi dan dispersi pada senyawa tersebut. Dan juga campuran tersebut akan menghambat difusi air dalam material, yang dikarenakan sifat hidrofobnya. Sehingga diharapkan dapat menghasilkan beton yang kuat dan tidak tembus air. Pada penelitiannya, campuran adukan beton dilakukan penambahan serbuk kayu sebanyak $5 \mathrm{gr} / \mathrm{kubus,} \mathrm{dengan} \mathrm{jumlah} \mathrm{semen} 325$ $\mathrm{kg} / \mathrm{m}^{3}$, faktor air semen (fas) nya 0,55 dan berat beton $2380 \mathrm{Kg} / \mathrm{m}^{3}$. Dari hasil pengujian, dengan penambahan serbuk kayu sebanyak 5 gr/kubus terjadi peningkatan kuat tekan beton sebesar 138,90 Kg/cm², atau kuat tekan betonnya terjadi peningkatan sebesar 1,08 \% dibandingkan dengan beton normal (tanpa penambahan serbuk) yaitu $127,78 \mathrm{Kg} / \mathrm{cm}^{2}$. 
Sitompul (2016), pada penelitiannya melakukan penambahan serbuk kayu Meranti dari industri penggergajian di Medan sebagai bahan campuran agregat halus pada campuran betonnya dengan variasi 3\%, 6\% dan 9\%, dengan benda uji kubus $15 \mathrm{~cm}$ x $15 \mathrm{~cm}$ dan kuat tekan rencana $\mathrm{f}^{\prime} \mathrm{c}=30 \mathrm{Mpa}$. Dari hasil pengujian kuat tekan setelah beton mencapai umur 28 hari, dengan penambahan serbuk kayu Meranti 3\%, 6\% dan 9\% pada campuran beton, didapat mutu beton 26,92 Mpa, 15,98 Mpa dan 22,03 Mpa, dengan persentase penurunan pada berat beton sebesar 10,26\%, 16,73\%, dan 26,57\% dari beton normal (30,08 Mpa). Hadi (2018) di dalam penelitiannya melakukan pengujian pada 9 buah benda uji silinder beton berukuran diameter $150 \mathrm{~mm}$ dan tinggi $300 \mathrm{~mm}$, dengan perbandingan campuran beton 1Pc: 2Ps: 3Ba. Benda uji dibuat menjadi 3 bagian yaitu 3 buah kondisi normal (0\%) menghasilkan kuat tekan rata-rata beton ringan 17,342 Mpa, 3 buah dengan penambahan kertas $10 \%$, kuat tekannya 20,324 Mpa, dan 3 buah dengan penambahan kertas 20\%, kuat tekannya 18,874 Mpa. Sehingga disimpulkan bahwa penambahan limbah kertas $10 \%$ menghasilkan beton ringan dengan kuat tekan tertinggi sebesar 20,324 Mpa

Menurut KBBI (2005), limbah adalah sisa bahan atau sisa proses produksi yang tidak berharga dan tidak mempunyai nilai. Kayu adalah bahan yang didapat dari hasil penebangan pohon di hutan. Suatu industri pengolahan kayu didalam proses produksinya akan menghasilkan suatu buangan atau limbah berupa sisa yang dibiarkan akan membusuk dan terkadang dibakar dengan maksud mengurangi volume limbah yang terjadi (Nada \& Suryatmaja,2013). Akan tetapi hal ini akan berdampak negatif terhadap lingkungan dan jika tidak dikelola dengan baik akan menimbulkan pencemaran pada lingkungan sekitarnya. Serbuk gergaji terjadi dari proses pemotongan kayu dengan cara digergaji yang menghasilkan butiran-butiran halus (Setiyono, 2004). Limbah hasil gergajian yang dihasilkan antara satu pabrik gergajian dengan yang lainnya akan berbeda, karena pengaruh berbagai faktor, di mana besar kecilnya jumlah limbah yang dihasilkan sangat tergantung dari rendah dan tinggi rendah angka rendemen. Rendemen adalah angka perbandingan barang yang dihasilkan dan bahan baku yang dipakai, yang dinyatakan dalam persen $(\%)$, seperti tabel berikut :

Tabel 1.Komposisi Bentuk Limbah Penggergajian

\begin{tabular}{|l|c|}
\hline \multicolumn{1}{|c|}{ Bentuk / Jenis Limbah } & Nilai Persentase (\%) \\
\hline Serbuk gergaji & $12-15$ \\
\hline Sabetan dan potongan ujung berukuran kecil & $25-35$ \\
\hline Potongan dolok dan kayu cacat & $5-10$ \\
\hline
\end{tabular}

Sumber: Rachman dan Malik (2011) [8]

Kertas menurut jenisnya termasuk limbah organik. Menurut KBBI (2008), kertas adalah bahan berbentuk lembaran yang dibuat dari bubur berbahan kayu, jerami, rumput, dan lain sebagainya, yang digunakan untuk alat tulis. Kertas merupakan sebuah material dengan bentuk yang sangat tipis dan dibuat dari serat alamiah dan kertas adalah sebuah revolusi sebuah alas tulis non alami seiring pergantian peradaban dari jaman ke jaman

Beton mempunyai sifat getas, mempunyai kuat tekan yang tinggi tetapi rendah kuat tariknya. Kuat tekan beton sangat berhubungan dengan sifat-sifat yang lainnya, dimana bila kuat tekan betonnya tinggi, maka sifat-sifat lainnya akan baik (Kardiyono, 2007). Komponen beton terdiri dari : (1) semen portland yang mengandung kalsium dan alumunium silica dengan bahan dasar batu kapur dengan kandungan $\mathrm{CaO}$, dan tanah liat 
atau lempung (Setiawan, 2016); (2) Agregat sebagai komponen utama yang paling berperan dalam pembentuk beton, yang berupa pasir, kerikil (batu pecah) (Edwar G. Nawy dalam Amiwarti \& Mahipal, 2019); (3) Air yang digunakan adalah air yang layak untuk diminum. Menurut Depkimpraswil (dalam Saifuddin, dkk (2013), kuat tekan beton adalah besarnya beban persatuan luas, yang membuat hancurnya benda uji bila diberi gaya tekan tertentu dari mesin tekan. Sifat dan karakteristik bahan pembuat beton akan berpengaruh pada kinerja beton, dimana beton yang akan diproduksi harus sesuai dengan mutu dan beton (Mulyono, 2004), dimana berdasarkan SNI-03-1974-1990 dalam Hamdi dkk (2019) seperti tabel berikut :

Tabel 2. Kelas dan Mutu Beton

\begin{tabular}{|c|c|c|c|}
\hline $\begin{array}{c}\text { Kelas } \\
\text { Beton }\end{array}$ & Mutu Beton & $\begin{array}{c}\text { Kekuatan Tekan } \\
\left(\mathrm{Kg} / \mathrm{cm}^{2}\right)\end{array}$ & Tujuan Pemakaian Beton \\
\hline I & Bo & $50-80$ & Non-Struktural \\
\hline II & B1 & 100 & Rumah Tinggal \\
& K125 & 125 & Perumahan \\
& K175 & 175 & $\begin{array}{c}\text { Perumahan } \\
\end{array}$ \\
K225 & 225 & Perumahan dan Bendungan \\
\hline III & K $>225$ & $>225$ & $\begin{array}{c}\text { Jembatan, Bangunan Tinggi, } \\
\text { Terowongan Kereta Api }\end{array}$ \\
\hline
\end{tabular}

\section{METODE PENELITIAN}

Standar pencampuran material beton yang digunakan mengikuti aturan standar SNI, yaitu $1: 2: 3$ (perbandingan semen : pasir : kerikil), dengan komposisi material sesuai standar SNI dengan mutu beton K.175 dan komposisi untuk $1 \mathrm{~m} 3$ nya terdiri dari $326 \mathrm{~kg}$ semen, $760 \mathrm{~kg}$ pasir dan $1029 \mathrm{~kg}$ kerikil, dimana untuk sampel dibuat 5 buah diperlukan $5,5 \mathrm{~kg}$ semen, $12,8 \mathrm{~kg}$ pasir, 17,3 kg kerikil. Pencampuran ini dilakukan dengan penambahan volume campuran limbah serbuk gergaji dan kertas dengan cara mengurangi volume campuran beton normal, yaitu sebagai berikut : (1) Campuran serbuk gergaji 5\% dan kertas 5\%; (2) Campuran serbuk gergaji 5\% dan kertas 10\%; (3) Campuran serbuk gergaji 5\% dan kertas 15\%; (4) Campuran serbuk gergaji 10\% dan kertas 5\%; (5) Campuran serbuk gergaji 15\% dan kertas 5\%. Dan adukan beton normal yang digunakan adalah adukan 1:2:3 sesuai standar SNI (K.175).

Bahan campuran yang sudah siap, kemudian diaduk dengan cangkul secara manual, di mana bahan yang digunakan tanpa melalui pengujian laboratorium terlebih dahulu. Hal ini dimaksudkan untuk mendapatkan hasil yang sesuai pelaksanaan dan mendekati kondisi yang sebenarnya di lokasi kerja. Pada tahap awal pasir dan kerikil (koral) diaduk, kemudian semen dicampur ke adukan pasir dan kerikil yang telah diaduk rata. Dan setelah ketiganya tercampur rata, masukkan air sedikit demi sedikit kemudian diaduk. Selanjutnya limbah serbuk gergaji dan kertas dicampurkan ke dalam adukan dan diaduk hingga semua campuran rata. Selanjutnya dibuat benda uji beton kubus. Di mana pada hari kedua setelah benda uji dicetak, benda uji direndam dalam air selama 25 hari kedepan, dan setelah umur 26 hari benda uji diangkat dan di angin-anginkan sampai umur 28 hari. Setelah benda uji berumur 28 hari dilakukan pengujian kuat tekan beton. 


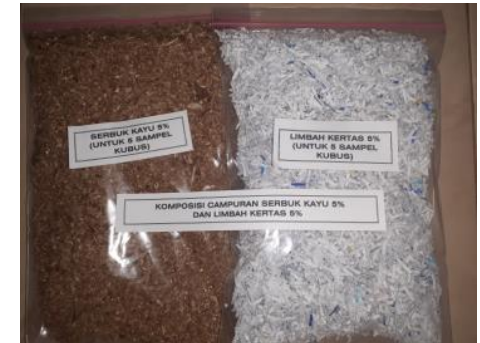

(Serbuk gergaji dan limbah kertas)

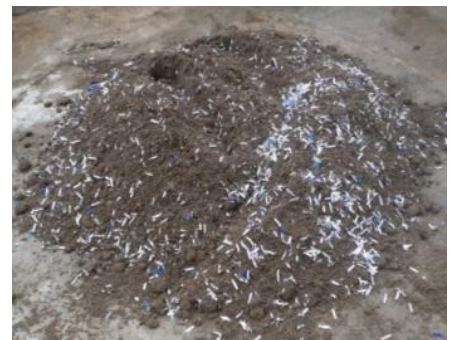

(campuran adukan)

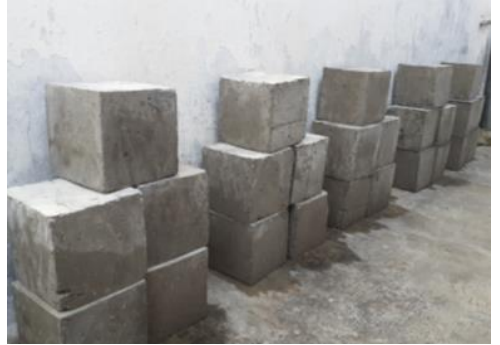

(benda uji)

Gambar 1. Proses Pembuatan Benda Uji

\section{HASIL DAN PEMBAHASAN}

Dari hasil pengujian didapat hasil sebagai berikut :

a) Komposisi beton normal (tanpa penambahan serbuk gergaji dan kertas / SO.L0)

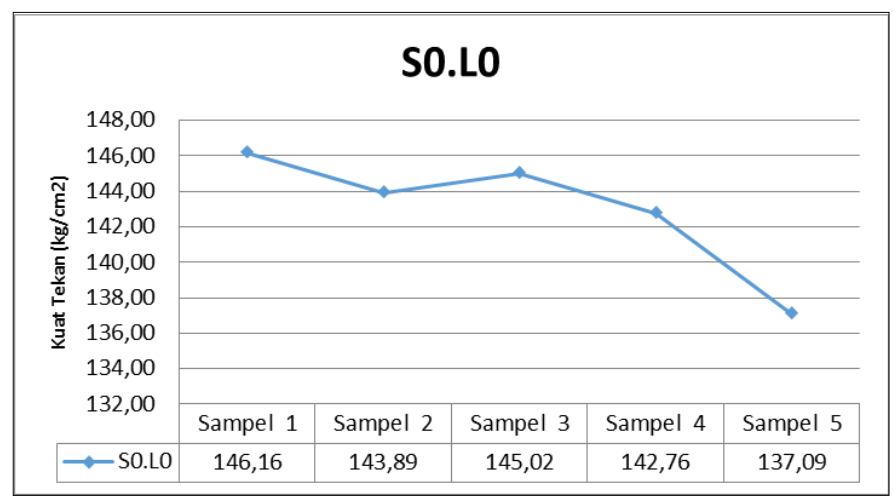

Gambar 2. Grafik Komposisi S0.L0

Dari grafik diatas, mutu beton hasil yang dihasilkan masih tidak memenuhi standar yang ditetapkan yaitu K.175. Di mana rata-rata untuk beton normal, hasil pengujiannya didapat mutu sebesar $144,46 \mathrm{~kg} / \mathrm{cm} 2$

b) Komposisi beton normal ditambah serbuk gergaji 5\% dan kertas 5\% (S5.L5)

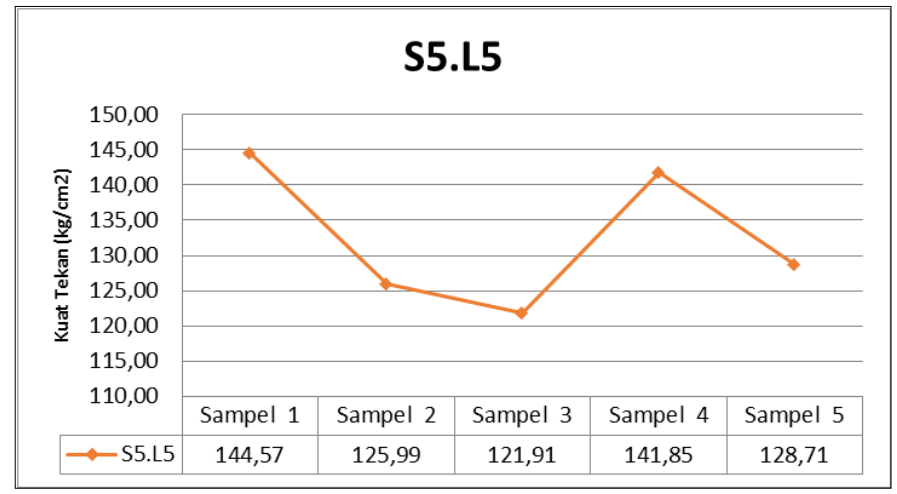

Gambar 3. Grafik Komposisi S5.L5

Dari grafik diatas, mutu beton rata-rata sebesar $132,61 \mathrm{~kg} / \mathrm{cm} 2$ dan masih belum memenuhi standar yang ditetapkan yaitu K.175 
c) Komposisi beton normal ditambah serbuk gergaji 5\% dan kertas 10\% (S5.L10)

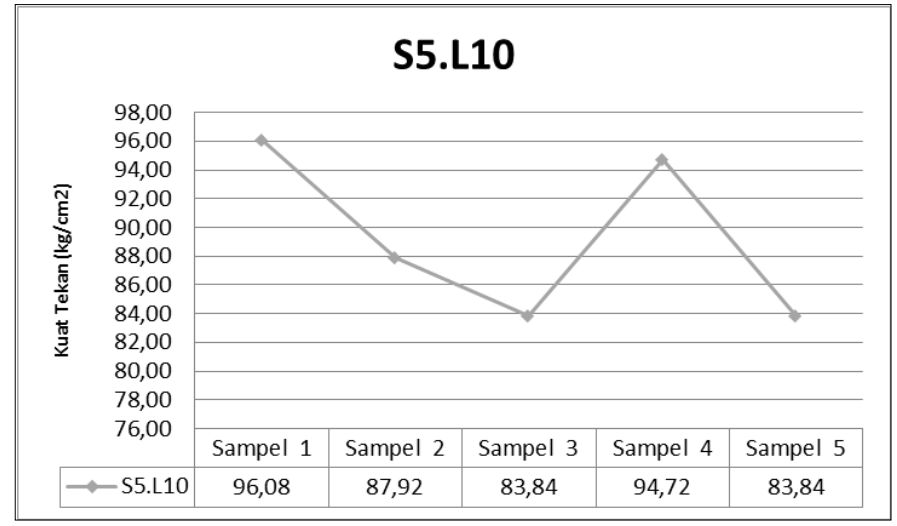

Gambar 4. Grafik Komposisi S5.L10

Dari grafik diatas, mutu beton rata-rata sebesar $89,28 \mathrm{~kg} / \mathrm{cm} 2$ dan masih belum memenuhi standar yang ditetapkan yaitu K.175

d) Komposisi beton normal ditambah serbuk gergaji 5\% dan kertas 15\% (S5.L15)

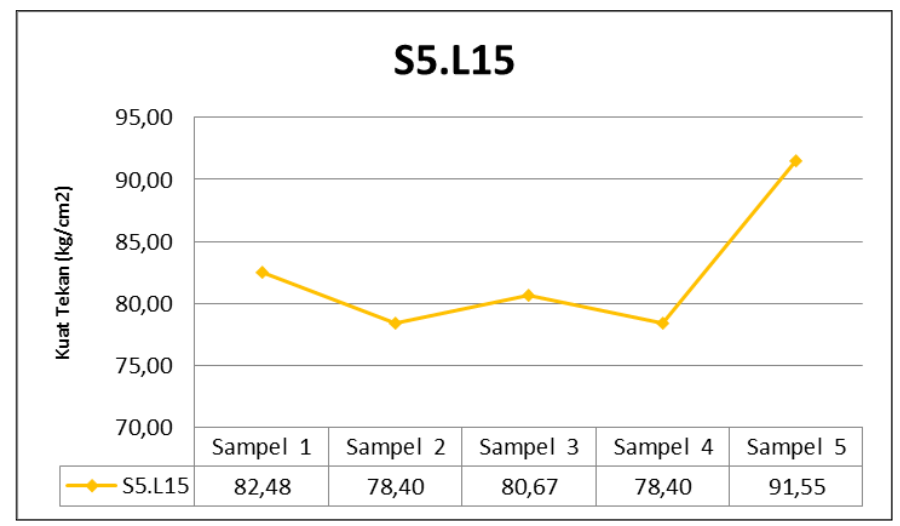

Gambar 5. Grafik Komposisi S5.L15

Dari grafik diatas, mutu beton rata-rata sebesar $82,30 \mathrm{~kg} / \mathrm{cm} 2$ dan masih belum memenuhi standar yang ditetapkan yaitu K.175

e) Komposisi beton normal ditambah serbuk gergaji 10\% dan kertas 5\% (S10.L5)

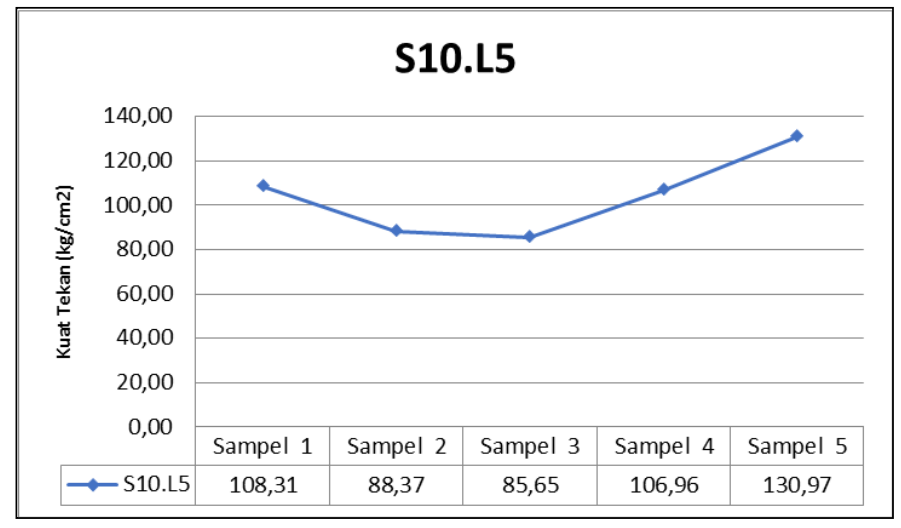

Gambar 6. Grafik Komposisi S10.L5 
Dari grafik diatas, mutu beton rata-rata sebesar 104,05 kg/cm2 dan masih belum memenuhi standar yang ditetapkan yaitu K.175

f) Komposisi beton normal ditambah serbuk gergaji 15\% dan kertas 5\% (S15.L5)

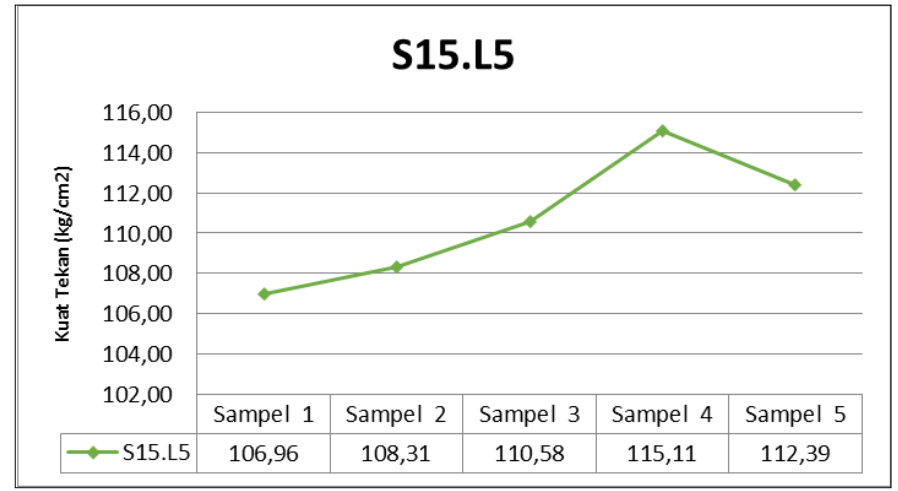

Gambar 7. Grafik Komposisi S15.L5

Dari grafik diatas, mutu beton rata-rata sebesar $110,67 \mathrm{~kg} / \mathrm{cm} 2$ dan masih belum memenuhi standar yang ditetapkan yaitu K.175

Sehingga dapat dirangkum dalam gambar grafik berikut :

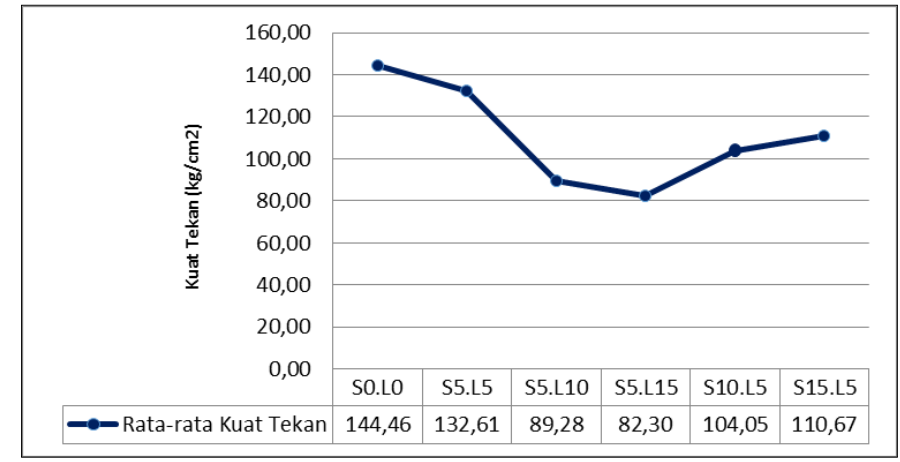

Gambar 8. Grafik Hasil Kuat Tekan Beton

Dari semua pengujian didapatkan hasil dengan mutu beton yang masih dibawah standar rencana yaitu K.175 (komposisi adukan 1:2:3), termasuk juga beton normal, hal ini dimungkinkan pada penggunaan agregat, khususnya pasir Sungai Musi sebagai agregat halus, karena pasir Sungai Musi banyak mengandung lumpur. Sehingga seharusnya sebelum penggunaan sebagai campuran beton, pasir Sungai Musi harus dicuci dahulu.

\section{KESIMPULAN}

Dari pengujian kuat tekan beton yang dilakukan, terjadi penurunan kuat tekan dari setiap campuran beton, di mana nilai kuat tekan beton terbesar yaitu 132,61 kg/cm2 terjadi di komposisi campuran beton normal ditambah serbuk gergaji 5\% dan kertas 5\% (S5.L5). Sehingga dapat disimpulkan bahwa campuran beton normal ditambah serbuk gergaji dan kertas dengan pelaksanaan tanpa perlakuan khusus tidak mencapai mutu beton rencana yaitu mutu K.175 dengan komposisi adukan 1:2:3. Hal ini dimungkinkan penggunaan pasir Sungai Musi sebagai agregat halus, karena pasir Sungai Musi banyak mengandung lumpur. 


\section{DAFTAR PUSTAKA}

Amiwarti, A., \& Mahipal, M. (2019). Analisa Pengaruh Serbuk Kaca dan Abu Terbang Sebagai Bahan Pengganti Alternatif Terhadap Kuat Tekan Beton. Jurnal Deformasi, 4(1), 1-12.

Hadi, H. S. (2018). Analisis Penambahan Limbah Kertas Terhadap Kuat Tekan Beton Ringan, Ganec Swara, 12(1), 94-98.

Hamdi, H., Dafrimon, D., Harijadi, S., \& Revias, R. (2019). Pengaruh Penambahan Kawat Bendrat Galvanis pada Campuran Beton Terhadap Kuat Lentur Beton. Jurnal Deformasi, 4(1), 30-43.

Mulyono Tri (2004). Teknologi Beton. Penerbit Andi, Yogyakarta.

Nada, I. M., \& Suryatmaja, I. B. (2013). Karakteristik Fisik Campuran Batu Bata Dengan Memanfaatkan Abu Sisa Pembakaran Limbah Kayu. Kurva Teknik, 2(1), 88-97.

Purwanto, H. (2016). Kajian Desain Beton Pracetak Sebagai Salah Satu Alternatif Jembatan Bentang Pendek. Jurnal Deformasi, 1(1), 28-42.

Rachman O dan Malik J. (2011). Penggergajian dan permesinan kayu untuk industri perkayuan Indonesia. Balai Penelitian dan Pengembangan Kehutanan, Jakarta.

Saifuddin, M. I., Edison, B., \& Fahmi, K. (2013). Pengaruh Penambahan Campuran Serbuk Kayu Terdahap Kuat Tekan Beton. Jurnal Mahasiswa Teknik, 1(1).

Setiawan Agus (2016). Perancangan struktur beton bertulang berdasarkan SNI 2847 : 2013. Program Studi Teknik Sipil Universitas Pembangunan Jaya. Penerbit Erlangga.

Setiyono. 2004. Pedoman Teknis Pengelolaaan Limbah Industri Kecil. Kementrian Lingkungan Hidup, Jakarta

Sitompul, S. F. P. (2016). Pengaruh variasi penambahan serbuk kayu Meranti terhadap kuat tekan beton pada umur 28 hari. (Doctoral dissertation, UNIMED).

Tjokrodimuljo Kardiyono (2007). Teknologi Beton. Biro Penerbitan Teknik Sipil dan Lingkungan Universitas Gadjah Mada.

2005. Kamus Besar Bahasa Indonesia (KBBI) Edisi 3. Jakarta : Balai Pustaka 2008. Kamus Besar Bahasa Indonesia (KBBI) Edisi 4. Jakarta : Balai Pustaka. 